\title{
PENGARUH KUALITAS LAYANAN YANG TERDIRI DARI KENYAMANAN, KEAMANAN, KEMUDAHAN DAN FASILITAS TERHADAP KEPUASAN KONSUMEN PADA GALERI SENI DAN PUSAT MEDITATION PONOROGO JAWA TIMUR
}

\author{
*(Emmywati \\ Prodi Manajemen, Sekolah Tinggi Ilmu Ekonomi Mahardhika Surabaya \\ JL. Wisata Menanggal 42 A Surabaya \\ Email:emmywati1606@gmail.com
}

\begin{abstract}
ABSTRAK
Penelitian ini ditujukan untuk menganalisis pengaruh kualitas pelayanan khususnya berdasar dimensi kualitas jasa yaitu terdiri dari variabel-variabel : kenyamanan, kemudahan, keamanan, dan fasilitas. Variabel-variabel tersebut digunakan untuk menganalisis pengaruh kualitas pelayanan terhadap kepuasan konsumen di galeri seni dan meditation ki ageng mirah Ponorogo. Penelitian ini bertujuan: (1) Untuk mengetahui kualitas kepuasan konsumen Galeri Seni dan Meditation Ki Ageng Mirah Ponorogo (2) Untuk menganalisis kualitas kenyamanan, kemudahan, keamanan dan fasilitas Galeri Seni Dan Meditation Ki Ageng Mirah Ponorogo (3) Untuk menganalisis variabel apa yang paling dominan dari dimensi kualitas pelayanan Galeri Seni Dan Meditation Ki Ageng Mirah Ponorogo yang mempengaruhi kepuasan konsumen. Sampel yang digunakan dalam penelitian ini adalah 85 responden, teknik pengambilan sampel ditentukan dengan Convinience Sampling. Alat analisis yang digunakan adalah analisis uji regresi linear berganda, koefisien determinasi (R2), koefisien korelasi parsial, ujit, uji $F$ dan uji asumsi klasik dengan menggunakan program SPSS versi 17 forwindows.Data primer ini diperoleh dari kusioner yang pengukurannya menggunakan skala Likert yang diuji validitas dan reliabilitas. Hasil penelitian berdasarkan uji $t$ dan uji $f$ menunujukkan bahwa kualitas kenyamanan dan keamanan berpengaruh paling signifikan terhadap kepuasan konsumen karena mempunyai korelasi yang paling besar dibandingkan variable bebas lainnya. Variabel kenyamanan, kemudahan, keamanan dan fasilitas mempunyai hubungan kuat dan searah terhadap kepuaasan konsumen GaleriSeni Dan Meditation Ki Ageng Mirah Ponorogo dilihat dari nilai korelasi dan nilai koefisien determinasi. Ini berarti variabel kenyamanan,kemudahan, keamanan, dan fasilitas mempunya pengaruh besar terhadap kepuasan konsumen sedangkan sisanya dipengaruhi oleh variabel lain diluar penelitian ini.
\end{abstract}

Kata kunci :Kualitas Layanan, Kenyamanan, Kemudahan, Keamanan, Fasilitas dan Kepuasan.

\section{PENDAHULUAN}

Pada era globalisasi saat ini, persaingan dalam bidang usaha semakin bertambah ketat. Persaingan ini menuntut para pengusaha untuk mampu memaksimalkan kinerja usaha yang di gelutinya agar dapat bersaing di pasar. Pengusaha harus berusaha keras untuk mempelajari dan memahami kebutuhan dan keinginan pelanggannya. Dengan memahami kebutuhan, keinginan dan permintaan pelanggan, maka akan memberikan 
masukan penting bagi usahanya untuk merancang strategi pemasaran agar dapat menciptakan kepuasan bagi pelanggannya. Dalam kondisi persaingan yang ketat seperti ini, hal utama yang harus diprioritaskan oleh sebuah bidang usaha yang bergerak dalam bidang pelayanan adalah kepuasan pelanggan agar dapat bertahan, bersaing, dan menguasai pangsa pasar. Dengan menyadari bahwa sebenarnya nilai merupakan sintesa dari sejumlah hal yang diantaranya adalah kualitas dan pelayanan pelanggan, maka keputusan atau ketidakpuasan pelanggan menjadi topik yang menarik untuk dibicarakan dan dibahas pada setiap kesempatan yang ada.

Kepuasan

pelanggan ditentukan oleh kualitas barang dan jasa yang dikehendaki pelanggan, sehingga jaminan kualitas menjadi prioritas utama bagi setiap usaha sebagai tolak ukur keunggulan daya saing tersebut. Kualitas pelayanan dalam perusahaan jasa merupakan hal yang sangat penting dari sudut pandang konsumen. Konsumen tidak hanya menilai dari hasil jasa, tetapi juga dari proses penyampaian jasa, kwalitas produk yang di tawarkan oleh suatu bidang usaha. Pelanggan diibaratkan seorang raja yang harus dilayani, namun hal ini bukan berarti menyerahkan segala-galanya kepada pelanggan. Usaha memuaskan kebutuhan pelanggan harus dilakukan secara menguntungkan atau bersifat "win-win situation" yaitu dimana kedua belah pihak merasa senang atau tidak ada yang dirugikan. Kepuasan pelanggan merupakan suatu hal yang sangat berharga demi mempertahankan keberadaan pelanggannya tersebut untuk tetap berjalannya suatu bisnis atau usaha (Chandra danFandy, 2011).
Kotler (2012) berpendapat bahwa perusahaan-perusahaan yang bergerak dalam bidang jasa merupakan bisnis yang berdasarkan pada azas kepercayaan sehingga masalah kualitas pelayanan menjadi faktor yang sangat menentukan dalam keberhasilan usaha. Kualitas pelayanan dan produk merupakan suatu bentuk penilaian konsumen terhadap tingkat layanan yang diterima (perceived service) dengan tingkat layanan yang diharapkan (expected service). Agar dapat bersaing, bertahan hidup, dan berkembang, maka perusahaan perbankan dituntut untuk mampu memberikan pelayanan berkualitas yang dapat memenuhi kebutuhan dan keinginan pelanggan. Galeri Seni dan Meditation Ki Ageng Mirah yang bergerak dalam bidang jasa pelatihan dan menyediakan produk alami berupa batu permata, batu mulia dan benda seni lainya ini mempunyai visi " terwujudnya pelestarian seni dan budaya untuk menumbuhkan masyarakat yang mencintai khasanah budaya bangsa ". Sedangkan misinya adalah "Meningkatkan layanan prima yang didukung oleh kehandalan Sumber Daya Manusia dengan teknologi modern serta jaringan yang luas, membangun budaya dan mempertahankan kelestarian budaya baik fisik dan non fisik".Dengan adanya visi dan misi tersebut sudah tentu Galeri Seni dan Meditation Ki Ageng Mirah harus selalu melakukan pelayanan pada azas kepercayaan sehingga masalah kualitas pelayanan terhadap pelanggan menjadi faktor yang sangat menentukan keberhasilan bisnis jasa ini.

\section{Pengertian Kualitas Layanan}

Kata kualitas mengandung banyak definisi dan makna karena orang yang berbeda akan 
mengartikannya secara berlainan, seperti kesesuaian dengan persyaratan atau tuntutan, kecocokan untuk pemakaian perbaikan berkelanjutan, bebas dari kerusakan atau cacat, pemenuhan kebutuhan pelanggan, melakukan segala sesuatu yang membahagiakan. Dalam perspektif TQM (Total Quality Management) kualitas dipandang secara luas, yaitu tidak hanya aspek hasil yang ditekankan, tetapi juga meliputi proses, lingkungan dan manusia. Hal ini jelas tampak dalam defenisi yang dirumuskan oleh Goeth dan Davis yang dikutip Tjiptono (2012:51) bahwa kualitas merupakan suatu kondisi dinamis yang berhubungan dengan produk, jasa, manusia, proses, dan lingkungan yang memenuhi atau melebihi harapan. Sebaliknya, definisi kualitas yang bervariasi dari yang kontroversional hingga kepada yang lebih strategik. Menurut Garvin yang dikutip Tjiptono (2012:143) menyatakan bahwa terdapat lima perspektif mengenai kualitas, salah satunya yaitu bahwa kualitas dilihat tergantung pada orang yang menilainya, sehingga produk yang paling memuaskan preferensi seseorang merupakan produk yang berkualitas paling tinggi. Pelayanan dapat didefinisikan sebagai segala bentuk kegiatan/aktifitas yang diberikan oleh satu pihak atau lebih kepada pihak lain yang memiliki hubungan dengan tujuan untuk dapat memberikan kepuasan kepada pihak kedua yang bersangkutan atas barang dan jasa yang diberikan.

Pelayanan memiliki pengertian yaitu terdapatnya dua unsur atau kelompok orang dimana masingmasing saling membutuhkan dan memiliki keterkaitan, oleh karena itu peranan dan fungsi yang melekat pada masing-masing unsur tersebut berbeda. Hal-hal yang menyangkut tentang pelayanan yaitu faktor manusia yang melayani, alat atau fasilitas yang digunakan untuk memberikan pelayanan, mekanisme kerja yang digunakan dan bahkan sikap masing-masing orang yang memberi pelayanan dan yang dilayani.

\section{Kenyamanan}

Ada tiga tipe kenyamanan menurut Kolcaba, yaitu: relief yang berarti ketika kenyamanan spesifik yang dibutuhkan klien terpenuhi, ease berarti ketika klien merasa tenang dan puas, dan yang terakhir adalah transcendence ketika klien berhasil melampaui kebutuhan nyaman (Tomey \& Alligood, 2010). Kenyamanan dalam memperoleh pelayanan ini berkaitan dengan lokasi, ruangan, ketersediaan informasi.

\section{Keamanan ( Security )}

Keamanan adalah keadaan bebas dari bahaya. Istilah ini bias digunakan dengan hubungan kepada kejahatan, segala bentuk kecelakaan, dan produk-produk pada suatu perusahaan baik yang berupa barang maupun yang berupa jasa.Keamanan (security), adanya suatu kepercayaan yang tinggi dari pelanggan akan pelayanan yang diterima. Tentunya pelayanan yang diberikan mampu memberikan suatu jaminan kepercayaan. Keamanan ini meliputi keamanan fisik berupa produk atau jasa, keamanan informasi dan keamanan finansial.

\section{Kemudahan}

Kemudahan dalam kaitannya dengan kepuasan konsumen adalah kemudahan yang ditawarkan produsen kepada konsumen. Kemudahankemudahan yang mungkin ditawarkan oleh produsen, kemudahan dalam bertransaksi, kemudahan dalam berkomunikasi produsen. Kemudahan 
dalam menggunakan produk yang diberikan oleh suatu jenis jasa.

\section{Fasilitas}

Menurut Youti (2010:12) fasilitas adalah segala sesuatu baik benda maupun jasa yang menyertai pelayanan yang diberikan oleh perusahaan baik perusahaan jasa, dagang maupun perusahaan industri. Fasilitas dapat juga diartikan sebagai sarana dan prasarana yang tersedia dilingkungan maupun di dalam kantor perusahaan, dimaksudkan untuk memberikan pelayanan maksimal agar konsumen atau pelanggan merasakan nyaman dan puas. Fasilitas merupakan factor penunjang utama dalam kegiatan suatu produk. Raharjani (2005) menyatakan bahwa apabila suatu perusahaan jasa mempunyai fasilitas yang memadai sehinggga dapat memudahkan konsumen dalam menggunakan jasanya dan membuat nyaman konsumen dalam menggunakan jasanya tersebut tersebut maka akan dapat mempengaruhi konsumen dalam melakukan pembelian jasa.

Perusahaan yang memberikan suasana menyenangkan dengan desain fasilitas yang menarik akan mempengaruhi konsumen dalam melakukan pembelian. Artinya bahwa salah satu faktor kepuasan konsumen dipengaruhi oleh fasilitas yang diberikan oleh penjual yang dimanfaatkan oleh konsumen sehingga mempermudah konsumen dalam proses pembelian. Apabila konsumen merasa nyaman dan mudah mendapatkan produk atau jasa yang ditawarkan oleh penjual, maka konsumen akan merasa puas. Menurut Kertajaya (2010) pemberian fasilitas yang memadai akan membantu meningkatkan empati konsumen terhadap setiap kondisi yang tercipta pada saat konsumen melakukan pembelian. Sehingga secara psikologis mereka akan memberikan suatu pernyataan bahwa mereka puas dalam melakukan pembeliannya. Hal-hal yang perlu disampaikan dalam fasilitas jasa antara lain (1) kelengkapan, kebersihan dan kerapihan fasilitas yang ditawarkan, (2) kondisi dan fungsi fasilitas yang ditawarkan, (3) kemudahan penggunaan fasilitas yang ditawarkan, (4) kelengkapan alat yang digunakan fasilitas merupakan sarana penunjang yang digunakan perusahaan dalam usaha untuk meningkatkan kepuasan pelanggan. Semakin baik fasilitas yang diberikan kepada konsumen, maka akan semakin meningkatkan kepuasan konsumen. Kotler (2010) menyatakan bahwa salah satu upaya yang dilakukan manajemen perusahaan terutama yang berhubungan langsung dengan kepuasan konsumen yaitu dengan memberikan fasilitas sebaik-baiknya demi menarik dan mempertahankan pelanggan. Fasilitas merupakan sarana maupun prasarana yang penting dalam usaha meningkatkan kepuasan seperti memberi kemudahan, memenuhi kebutuhandan kenyamanan bagi pengguna jasa. Apabila fasilitas yang disediakan sesuai dengan kebutuhan, maka konsumen akan merasa puas.

\section{Kepuasan Pelanggan}

\section{Kepuasan}

merupakan salah satu kunci keberhasilan suatu usaha, hal ini dikarenakan dengan memuaskan pelanggan, perusahaan dapat meningkatkan pendapatan (profit) dan mendapatkan pangsa pasar yang lebih luas. Kepuasan pelanggan atau sering disebut juga dengan Total Customer Satisfaction menurut Barkley dan Taylor (Saleh, 2010:115) merupakan fokus dari proses Costomer-Driven Project Management (CDPM), bahkan dinyatakan pula bahwa kepuasan 
adalah kualitas. Menurut Kotler yang dikutip Tjiptono (2011) bahwa kepuasan pelanggan adalah tingkat perasaan seseorang setelah membandingkan kinerja (atau hasil) yang dirasakan dengan harapannya. Dengan demikian dapat diartikan bahwa kepuasan pelanggan merupakan perbedaan antara yang diharapkan pelanggan (nilai harapan) dengan situasi yang diberikan perusahaan di dalam usaha memenuhi harapan pelanggan. Sehingga yang menjadi indikator kepuasan pelanggan yang berfokus dari keinginan dan harapan pelanggan antara lain pelayanan memuaskan, pelayanan sesuai harapan, permasalahan terselesaikan, kesediaan merekomendasikan, dan minat penggunaan ulang.

\section{Kepuasan}

pelanggan

merupakan suatu tingkatan dimana kebutuhan, keinginan dan harapan dari pelanggan dapat terpenuhi yang akan mengakibatkan terjadinya kesetiaan berlanjut. Faktor yang paling penting untuk menciptakan kepuasan pelanggan adalah kinerja dan kualitas dari layanan yang diberikan oleh organisasi. Jadi tingkat kepuasan adalah fungsi dari perbedaan antara kinerja yang dirasakan dengan harapan. Kualitas termasuk semua elemen yang diperlukan untuk memuaskan tujuan pelanggan, baik internal maupun eksternal. Tingkat kepuasan yang diperoleh para pelanggan sangat berkaitan erat dengan standar kualitas barang/jasa yang mereka nikmati. Sifat kepuasan bersifat subjektif, namun dapat diukur melalui survey atau indeks kepuasan pelanggan masyarakat. Kepuasan pelanggan dibangun atas dasar beberapa prinsip yang digunakan untuk menilai suatu organisasi dalam memberikan pelayanan: tangibles (bukti nyata), reability ( terpercaya, tahan uji), responsiveness (respon,cepattanggap), assurance (kepastian), empathy (empati). Kepuasan pelanggan dapat dibedakan atas tiga taraf, yaitu (1) memenuhi kebutuhan kebutuhan dasar pelanggan, (2) memenuhi harapan pelanggan dengan cara yang dapat membuat mereka akan kembali lagi. Melakukan lebih daripada apa yang diharapkan pelanggan.

\section{METODE PENELITIAN}

Dalam penelitian ini digunakan suatu metode penelitian kuantitatif dimana penelitian kuantitatif adalah penelitian ilmiah yang sistematis terhadap bagian-bagian dan fenomena serta hubungan hubungannya. Tujuan penelitian kuantitatif adalah mengembangkan dan menggunakan model-model matematis, teori-teori atau hipotesis yang berkaitan dengan fenomena alam. Proses pengukuran adalah bagian yang sentral dalam penelitian kuantitatif karena hal ini memberikan hubungan yang fundamental antara pengamatan empiris dan ekspresi matematis dari hubungan-hubungan kuantitatif. Dalam hal ini pengujian Pengaruh Kualitas Layanan konsumen pada Galeri Seni dan Meditation Ki Ageng Mirah Aesthetic Ponorogo.

Populasi menurut Sugiyono (2010:215) merupakan wilayah generalisasi yang terdiri atas : obyek/subyek yang dipelajari mempunyai kualitas dan karakteristiktertentu yang ditetapkan oleh penelitiuntuk dipelajari dan kemudian ditarik kesimpulan . Populasi dapat pula dimaksudkan sebagai sekelompok organisasi, kejadian atau segala sesuatu yang mempunyai karakteristik tertentu . Populasi yang digunakan dalam penelitian ini adalah para pelanggan / 
konsumen Galeri Seni dan Meditation Ki Ageng Mirah Aesthetic yang sudah melakukan transaksi lebih dari 3 kali Sampel adalah bagian dari jumlah dan karakteristik yang dimiliki oleh populasi tersebut (Sugiyono,2010:81). Teknik penarikan sampel yang digunakan dalam penelitian ini adalah Non Probablity Sampling dengan teknik acidental Sampling yaitu teknik penentuan berdasarkankebetulan, yaitu siapa saja yangsecara kebetulan bertemu denganpeneliti dan dapat dijadikan sampel,bila dipandang orang yang kebetulanditemui itu cocok sebagai sumberdata (Sugiono, 2010:95). Jadi yang menjadi responden dalam penelitianini adalah para konsumen yang berkunjung pada Galeri Seni dan Meditation Ki Ageng Mirah Aesthetic.Dasar pengambilan jumlah sampel minimal didasarkan atas pendapat Roscoe dalam Uma Sekarang (20065) yang menyebutkan bahwa pada setiap penelitian, ukuran sampel minimal harus berkisar antara 30 dan 500. Untuk itu, Berdasar kanteori tersebut maka peneliti menetapkan jumlah sampel dalam penelitian ini sebesar 85 sampel .

\section{HASIL PENELITIAN DAN PEMBAHASAN}

\section{Uji Signifikansi Parameter} Individual (uji t)

Uji $t$ digunakan untuk mengetahui apakah variabel-variabel independen secara parsial berpengaruh nyata atau tidak terhadap variabel dependen. Derajat signifikan yang digunakan adalah 0,05. Pengambilan keputusan dengan tingkat signifikansi $(\square)=0,05: \mathrm{n}-1=84$, maka $\mathrm{t}$ tabel $=$ 1.663 ditentukan sebagai berikut:(1) Jika tingkat signifikansi $>0,05$ atau $\mathrm{t}$ hitung < t tabel, maka H0 ditolak; (2) Jika tingkat signifikansi $<0,05$ atau $\mathrm{t}$ hitung $>\mathrm{t}$ tabel, maka H0 diterima.
Berdasarkan hasil pengolahan data dalam SPSS maka di dapat hasil uji $\mathrm{t}$ sebagai berikut :

Tabel 1. Uji t (Parsial)

\begin{tabular}{|l|l|l|l|}
\hline Variabel & Hasil uji t & ttabel & Sig \\
\hline Kenyamanan & 4,580 & 1,663 & 0,000 \\
\hline Kemudahan & 2,771 & 1,663 & 0,000 \\
\hline Keamanan & 4,292 & 1,663 & 0,007 \\
\hline Faslitas & 1,166 & 1,663 & 0,000 \\
\hline
\end{tabular}

Sumber : Hasil Pengolahan DataSPSS 17

Hasil uji t diatas dari variable Kenyamanan, Kemudahan, Keamanan, dan Fasilitas keseluruhan variabel mempunyai nilai sig $<0,05$ dan nilai $t$ hitung $>t$ tabel, maka dapat disimpulkan keseluruhan variabel berpengaruh signifikan terhadap kepuasan pelanggan secara parsial diterima.

\section{Uji SignifikansiSimultan (uji F)}

Uji F digunakan untuk mengetahui apakah variabel-variabel independen secara simultan berpengaruh signifikan terhadap variabel dependen. Derajat kepercayaan yang digunakan adalah 0,05 . Ketentuan $\mathrm{f}$ tabel $: \mathrm{df} 1=\mathrm{m}=5$ df $2=\mathrm{n}-\mathrm{m}-1=85-4-1=80$. Keterangan $: \mathrm{n}=$ sampel, $\mathrm{m}=$ variabel bebas, maka $\mathrm{F}$ tabel $=2,33$. Kriteria pengujiannya adalah sebaga berikut ; (1) Jika tingkat signifikansi $F>0,05$ atau $\mathrm{F}$ hitung $<\mathrm{F}$ tabel, maka $\mathrm{H} 0$ diterima, (2) Jika tingkat signifikansi $\mathrm{F}<0,05$ atau $\mathrm{F}$ hitung $>\mathrm{F}$ tabel, maka H0 ditolak. Untuk analisis dari output SPSS dapat dilihat dari tabel "Anova". 
Tabel 2. Uji F (simultan)

\begin{tabular}{|l|l|l|l|l|l|}
\hline \multicolumn{7}{|c|}{ ANOVA $^{\text {b }}$} \\
\hline Model & $\begin{array}{l}\text { Sum of } \\
\text { Squares }\end{array}$ & df & $\begin{array}{l}\text { Mean } \\
\text { Square }\end{array}$ & F & Sig. \\
\hline $\begin{array}{l}\text { Regres } \\
\text { sion }\end{array}$ & 273.466 & 4 & 68.366 & $\begin{array}{l}483 . \\
542\end{array}$ & $.000^{a}$ \\
\hline $\begin{array}{l}\text { Residu } \\
\text { al }\end{array}$ & 11.311 & 80 & .141 & & \\
\hline Total & 284.776 & 84 & & & \\
\hline
\end{tabular}

a. Predictors: (Constant), X4, X2, X1, X3

b. Dependent Variable: $Y$

Sumber : Hasil Pengolahan Data SPSS 17 lihat pada table 1 . Bahwa t hitung $>\mathrm{t}$ table dan nilai signifikan $<0,05$; (2) hasil pengujian secara parsial (Uji t) menunjukkan bahwa variabel bebas yaitu kemudahan berpengaruh signifikan terhadap. Hal ini dapat di lihat pada table 1 bahwa $\mathrm{t}$ hitung $>\mathrm{t}$ tabel dan nilai signifikan $<0,05$.

Hasil pengujian secara parsial (Uji t) menunjukkan bahwa variabel bebas yaitu keamanan berpengaruh signifikan terhadap. Hal ini dapat di lihat pada table 1 . Bahwa $\mathrm{t}$ hitung $>\mathrm{t}$ tabel dan nilai signifikan $<0,05$. Hasil pengujian secara parsial (Uji t) menunjukkan bahwa variabel bebas yaitu fasilitas berpengaruh signifikan terhadap. Hal ini dapat di lihat pada table 1.Bahwa t hitung > ttabel dan niliasignifikan $<0,05$. Hasil pengujian secara simultan atau serempak (Uji F) menunjukkan bahwa variabel $\mathrm{f}$, variable kenyamanan, kemudahan, keamanan dan fasilitas, secara simultan berpengaruh serempak terhadap variable kepuasan konsumen galeri seni dan meditation ki ageng mirah Ponorogo. Hal ini dapat dilihat pada tabel 2. Bahwa nilai $F$ hitung $>F$ tabel. Hasil koefisien korelasi menunjukkan bahwa variabel kepuasan konsumen mempunyai pengaruh sebesar $96 \%$ terhadap variable terikat, sedangkan sisanya $4 \%$ dipengaruhi faktor -faktor lain diluar variabel penelitian.

\section{DAFTAR PUSTAKA}

Jeni Raharjani. 2005.Analisis Faktorfaktor yang Mempengaruhi Keputusan Pemilihan Pasar Swalayan Sebagai Tempat Berbelanja (Studi Kasus pada Pasar Swalayan di Kawasan Seputar Simpang Lima Semarang).Jurnal Studi Manajemen dan Organisasi, Vol. 2, No.1 Januari 2005, h. 1-15 
Kertajaya, Hermawan. 2010.Connect! Surfingnew Wave Marketing. Jakarta:GramediaPustaka Utama

Kotler, Philip. dan Gary. Armstrong. 2012. Prisip-prinsip Pemasaran. Edisi 13. Jilid 1. Erlangga. Jakarta.

Kotler, Philip. dan K.L. Keller.2010. Manajemen Pemasaran. Edisi Ketiga Belas. Jilid 1. Jakarta : Penerbit ErlanggaKotler, Philip. dan K.L. Keller. 2012. Manajemen Pemasaran. Edisi 13. Jilid 2. Erlangga. Jakarta

Oka A, Yoeti.2010. Dasar-dasar pengertian hospitaliti dan pariwisata.Bandung: Alumni

Roscoe dikutip dari Uma Sekaran. 2006. Metode Penelitian Bisnis. Jakarta : Salemba Empat

Saleh, M. A. (2010). Public Service Communication. Malang:UMM Press

Sugiyono. 2010. Metode Penelitian Kuantitatif Kualitatif dan $R \& D$. Bandung: Alfabeta.

Tjiptono, Fandy dan Gregorius Chandra .2011. Service, Quality dan Satisfaction.

Tomey, A.M. and Alligood.2010. Nursing theorist and their work $\left(7^{\text {ed }}\right)$. St. Louis : Mosby Elseveir. 